\title{
PENGARUH MODEL PEMBELAJARAN SUGGESTOPEDIA TERHADAP KETERAMPILAN BERPIKIR INDUKTIF IPA KELAS IV SDN KARANG TENGAH 12 KOTA TANGERANG
}

\author{
${ }^{1}$ Intan Pandini, ${ }^{2}$ Een Unaenah, ${ }^{3}$ Imam Muttaqijn \\ Universitas Muhammadiyah Tangerang, Indonesia \\ e-mail : ${ }^{1}$ pandinii39@gmail.com, 2 eenuna@gmail.com
}

\begin{abstract}
Abstrak
Penelitian inibertujuan untuk mengetahuipengaruh terhadap keterampilan berfikir indukt if siswa pada mata pelajaran Ilmu Pengertahuan Alam (IPA) materi ga ya, antara siswa yang diberikan Model Pembelajaran Suggestopediadengan siswa yang diberi pengajaran konvensional. Penelitian ini menggunakan metode penelitian quasi eksperimen dengandesain penelitian Nonequivalent Control Group Design. Subjek populasi dalampenelitian ini a dalah seluruh siswa kelas IV SDN Ka ran g Te ngah 12 ya ng berjumlah 112 siswa, dengan mengambil sampel dua kelas sebanyak 56 siswa y aitu kelas IVB yang berjumlah 28 siswa sebagai kelas eksperimen dan IVA yang berjumlah 28 siswa sebagai kela s kontrol. Teknik pengumpulan data dengan menggunakan instrumen soal tes keterampilan berfikir induktif berbentuk essay yang terdiri dari 10 soal yang telah valid. Untuk pengujian hipotesis pretes dalam penelitian ini digunakan ujit, da ri hasil ujit tersebut diperoleh diperoleh $\mathrm{t}_{\text {hitung }}=-0,2<\mathrm{t}_{\text {tabel }}=2,00$, $\mathrm{m}$ aka dapat disim pulkan bahwa tidak terdapat pengaruh yang signifikan antara ra ta-rata nila i pretes kelas kontrol dan kelas eksperimen. Sedangkan untuk pengujian hipot esis postes dari hasil ujit diperoleh $\mathrm{t}_{\mathrm{hitung}}$ $=7,55>\mathrm{t}_{\text {tabel }}=2,00$, maka dapat disimpulkan bahwa terdapatpengaruh y ang signifika $\mathrm{n}$ a nta ra ra ta - rata nilai postes kelas kontrol dan kelas eksperimen. Hal ini da pat diartikan bahwa keterampila n meny imak dengan menggunakan model pembelajaranSuggestopedia lebih tinggi daripa da m en ggunakan model pembelajaran konvensional.
\end{abstract}

Kata Kunci : ModelPembelajan Suggestopedia, Keterampilan Berpikir Induktif, Metode Quasi Eksperimen

\begin{abstract}
Abstrac
The purpose ofThis study aims to determine the influence of students' inductive thinking skills on natural science subject(IPA) material, between students given Suggestopedia Learning Models and students given conventional teaching, This study usedquantitative approach with a quasi eksperimental re sea rch method. The design used is Nonequivalent Control Group Design researchdesign. Population in this study were allfifth grade students of SDNKarang Tengah 12, amounting to 112 students, taking a sample of two classes as many as 56 students namelyIVB class totaling 28 students as an experimental class and IVA totaling 28 students as a control class. Data collection techniques used instruments test questions of essay inductive thinking skills consisting of 10 valid questions. To test the pretest hypothesis in this st udy used t test, from the results of the t test obtained obtained $t_{\text {count }}=-0,2<t_{\text {table }}=2.00$, it can be concluded that there is no significant effect between the average value of the control class and expe rimental class pretest. Whereas for testing the posttest hypothesis from the t test results obtained $t_{\text {count }}=7,55>t_{\text {table }}=$ 2.00 , it can be concluded that there is a significant influence between the average post te st value of the control class and the experimental class. This can mean that inductive thinking skills using the suggestopedia learning model is higher than using conventionallearning models.
\end{abstract}

Keywords: Suggestopedia learning model, induktif thinking skills, Quasi Experiment Method. 


\section{PENDAHULUAN}

Tingkat satuan pendidikan yang dianggap sebagai dasar pendidikan adalah Sekolah Dasar, pendidikan di sekolah dasar merupakan tempat awal untuk mengembangkan potensi yang ada pada diri siswa, melalui pendidikan siswa akan belajar dalam proses perubahan perilaku kearah yang lebih baik. Di sekolah siswa mengalami proses pendidikan awal dan pembelajaran yang mempunyai tingkat pemahaman dan kebutuhan pendidikan yang sesuai dengan dirinya.

Sekolah dasar merupakan suatu tempat untuk melakukan proses belajar mengajar ubtuk membina anak didik menjadi manusia berguna. Sekolah dasar mempunyai kurikulum dan beberapa mata pelajaran yang sudah di tetapkan oleh dinas pendidikan dan kebudayaan seperti pelajaran bahasa Indonesia, Matematika, Seni budaya, PKn, IPA, IPS, Agama, Penjaskes. Dari beberapa pelajaran yang sudah disebutkan dari dinas pendidikan dan kebudayaan.

Pembelajaran IPA adalah salah satu ilmu pengetahuan alam, yang sering disebut juga dengan istilah pendidikan saint, atau arti sempit sebagai disiplin ilmu dari physical sciences dan life sciences, yang termaksud physical sciences adalah ilmu-ilmu astronomi, kimia, goelogi, mineralogi, dan fisika; sedangkan life science meliputi biologi (anatomi,fisiologi, zoologi, citologi dan seterusnya). Pembelajaran IPA juga sebagai kumpulan pengetahuan yang tersusun secara sistematik, dan dalam penggunaanya secara umum terbatas pada gejala- gejala alam.Perkembanganya tidak hanya ditandai oleh adanya kumpulan fakta, tetapi oleh adanya motede ilmiah dan sikap ilmiah.

Ilmu Pengetahuan Alam (IPA) atau sering di sebut dengan pendidikan saint merupakan salah satu mata pelajaraan pokok dalam kurikulum pendidikan di Indonesia, termasuk pada jenjang sekolah dasar. Mata pelajaran IPA merupakan mata pelajaran yang di anggap sulit oleh sebagian peserta didik, mulai dari jenjang sekolah dasar sampai sekolah menengah. Anggapan sebagian peserta didik yang meny atakan bahwa pembelajaran IPA ini sulit adalah benar terbukti dari hasil perolehan Ujian Akhir sekolah (UAS) yang dilaporkan oleh Depdiknas masih sangat jauh dari standar yang diharapkan. 
Salah satu alternatif model pembelajaran yang dapat digunakan untuk mengasa keterampilan berfikir induktif siswa yaitu dengan model pembelajaran suggestopedia. Model pembelajan suggestopedia mampu menciptakan suasana, yaitu dengan cahaya yang lemah lembut, musik sayup-sayup, dekorasi ruangan yang ceria, tempat duduk yang menyenangkan dan tehnik dramatik yang digunakan guru dalam penyajian bahan pelajaran.Dalam aktifitas model pembelajaran suggestopedia dapat membuat siswa santai (tidak tegang), yang memungkinkan mereka membuka hati mereka secara sadar untuk belajar dengan nyaman dan tidak tertekan.

Dengan penerapan suggestopedia dimaksudkan untuk memberi sugesti atau pengaruh negatif yang tidak akan disadari bersemi pada diri siswa dan untuk menghilangkan perasaan takut yang menurut para ahli menghabat proses belajar seperti perasaan tidak mampu, perasaan takut salah, dan keprihatinan serta ketakutan akan sesuatu yang baru dan belum familiar. Dengan penerapan media pembelajaran suggestopedia diharapkan keterampilan berfikir induktif siswa dalam pembelajaran IPA ada peningkatan.

Keterampilan berpikir merupakan suatu kegiatan pola pemikiran untuk megolah pengetahuan yang telah diterima melalui panca indra dan ditunjukan untuk mencapai suatu kebenaran, dan penggunaan otak secara sadar untuk mencari sebab, berdebat, mempertimbangkan, memperkirakan dan mereflesikan suatu objek, keterampilan berfikir merupakan proses untuk meletih diri sendiri didalam batin dengan cara mempertimbangkan, merenungkan, menganalisis, membuktikan sesuatu, menunjukan alasan-alasan, menarik kesimpulan, meneliti suatu jalan pekiran, mencari hal yang berhubungan satu sama lain, mencari tau mengapa dan untuk apa sesuatu itu terjadi, dan membahas suatu realitas dengan menggunakan konsep atau berbagai pengertian.

Keterampilan berpikir induktif. Menurut Joyce, weil, dan calhoun (2009) "Keterampilan berfikir induktif merupakan keterampilan yang dapat membantu siswa mengumpulkan informasi kedalam konsep-konsep dan belajar memanipulasi kon sep konsep tersebut dengan secara bertahap dan strategis serta dapat meningkatkan kemampuan siswa dalam membentuk konsep secara efisien dan meningkatkn jangkauan perspektif dari sisi mana mereka memandang suatu informasi” (h.102). Menurut Winami (2015) "Keterampilan berfikir induktif adalah keterampilan berfikir yang menggunakan kejadian atau pengalaman yang sering dijumpai, disimpulkan menjadi 
kebenaran secara umum”. Menurut Miftahul huda (2014) “Keterampilan berfikir induktif (inductive thinking) mengasumsikan bahwa setiap manusia, termaksud siswa merupakan konseptor alamiah, yang artinya mereka selalu berusaha melakukan konseptualisasi setiap saat, membandingkan dan membedakan objek, kejadian dan emosi". Dapat disimpulkan bahwa keterampilan berpikir induktif adalah keterampilan yang pada dasarnya meningkatkan efektivitas siswa dalam membentu konse p, berfikir yang menggunakan kejadian atau pengalaman yang sering di jumpai secara umum serta meningkatkan pola pemahaman siswa melihat infomasi atau pendapat dari sudut pandang yang berbeda.

Prinsip keterampilan berpikir kemampuan berfikir merupakan suatu proses penekanan pada mental siswa secara maksimal, peningkatan kemampuan berfikir dibangun dalam nuansa dialogis dan proses tanya jawab secara terus-menerus. Prinsip kemampuan berfikir diantaranya sebagai berikut: 1 . Selalu bersikap konstektif yaitu memiliki sikap positif untuk semua jenis keterampilan berfikir dan hindari bersikap negatif. 2. Berfikir secara perlahan dan selalu berfikir secara mudah. 3. Melupakan rasa ego, kita perlu mengikis perasaan ego kita jika inginkan setiap keterampilan berfikir yang digunakan itu dapat bermanfaat.

Dalam penelitian ini, untuk meningkatkan keterampilan berpikir induktif diberikan model pembelajaran sebagai variabel bebas dalam penelitian ialah model pembelajaran Suggestopedia. Pengertian model pembelajaran menurut tiga teori yaitu, Menurut Bushman (2009) “ menjelaskan bahwa model pembelajaran suggestopediaadalah belajar seperti anak-anak melepaskan murid dari kungkungan belajar rasional ke arah belajar yang lebih intutif." Sedangkan menurut Lazonov (1978) dalam Syarif sumatri $(2015: 77)$ " model pembelajaran suggestopediaadalah konsep klinis hipnotis yang sempit sebagai sejenis pernayataan kesadaran yang statis, seperti tidur, serta dapat diubah.” Kemudian menurut Azhar Arsyad (2015), “ model pembelajaran suggestopedia pada dasarnya adalah model pembelajaran yang membasmi suggesti atau pengaruh negative yangut sebagian para tidak disadari bersemi pada diri anak didik dan untuk menghilangkan perasaan takut yang menurut sebagian para ahli sangat menghambat proses belajar seperti perasaan tidak mampu, perasaan takut salah, dan keprihatinan serta ketakutan akan sesuatu yang baru dan belum familiyar." 
Dengan demikian dapat disimpulkan model pembelajaran bahwa model pembelajaran suggestopedia adalah model pembelajaran yang memberikan suggesti yang membuat siswa merasa nyaman dalam pembelajaran dan menuntut guru dapat dengan baik membuang perasaan rasa takut,cemas, takut salah, kekhawatiran siswa akan pelajaran yang sulit dengan merubah pola pemikiran siswa tersebut dengan memberi suggesti secara perlahan dan memasuki ruang bawa sadar siswa sehingga siswa termotivasi akan belajar dan menyampaian guru dapat dipahami dengan baik oleh siswa.

Penelitian ini memberikan pengaruh terhadap keterampilan berpikir induktif sis wa dengan menggunakan model pembelajaran Suggestopedia ketika pada saat proses belajar pada mata pelajaran IPA dengan materi teks fiksi dan nonfiksi.

\section{METODE PENELITIAN}

Penelitian ini dilakukan dengan metode eksperimen semu (quasi eksperiment). Penelitian dilaksanakan di SDN Karang Tengah 12 Kota Tangerang Tahun Pelajaran 2017/2018. Populasi penelitian adalah kelas IV yang berjumlah 105 siswa, adapun sampel penelitian terdiri dari dua kelas yaitu kelas IVA dan IVB masing-masing kelas terdiri dari 28 siswa. Teknik pengambilan sampel menggunakan teknik sampling purposive (Sugiyono, 2016). Karena teknik pengambilan sampel dengan pertimbangan tertentu. Kelas yang terpilih sebagai sampel penelitian yaitu kelas IVB sebagai kelas eksperimen dan kelas VC sebagai kelas kontrol.

Data dalam penelitian ini berupa data kuantitatif. Data kuantitatif berupa hasil tes keterampilan berpikir induktif pada materi teks fiksi dan non-fiksi. Terdiri dari 20 soal keterampilan berpikir induktif, untuk melihat pengaruh dari pemberian perlakuan terhadap kelas eksperimen maupun kelas kontrol, maka baik kelas eksperimen maupun kelas kontrol diberikan pretes dan postes. Untuk pretes dan postes digunakan perangk at tes yang berbeda. Data hasil penelitian yang diperoleh selanjutnya dianalisis statistik deskriptif dan inferensial. Pengujian terhadap perbedaan rata-rata hasil postest menggunakan teknik statistik uji t test.

\section{HASIL DAN PEMBAHASAN}


Soal-soal yang telah dibuat oleh peneliti, terdiri dari 20 soal yang sudah di uji oleh pakar ahli yaitu pada dosen Bidang Mata Kuliah Ilmu Pengetahuan Alam (IPA) di Universitas Muhammadiyah Tangerang, indikator yang berasal dari silabus pembelajaran IPA. Adapun indicator mengamati yaitu: 1) Siswa dapat memahami tentang pengertian gaya, 2) Siswa dapat mendeskripsikan macam- macam gaya. Mengelompokan yaitu 1) Siswa dapat mengindentifikasi pengaruh benda terhadap keadaan dalam air, 2) Siswa dapat mengelompokan macam-macam gaya dalamkehidupan. Menafsirkan yaitu: 1) Siswa dapat menafsirkan gaya mempen garuhi bentuk benda, 2) Siswa dapat ian menyimpulkan tentang pengertian gaya, faktor-faktor yang mempengaruhi gaya. Menyimpulkan yaitu: 1) Siswa dapat menyimpulkan macammacam gaya dalam kehidupan,pengaruh gaya dalam gerak benda, pengaruh gaya dalam bentuk benda,pengaruh gaya kedaan benda di dalam air.

Berdasarkan indikator tersebut dibuat 20 soal yang diuji oleh pakar, setelah soal diuji oleh ahli pakar, semua soal layak digunakan dan telah memenuhi syarat validasi. Selanjutnya tes tersebut digunakan dalam penelitian. Hasil dari data penelitian kemudian diuji normalitas dan uji homogenitas, dan hasilnya dinyatakan memenuhi syarat normal dan homogen. Sehingga dapat dilakukan pengujian hipotesis terhadap tes keterampilan menyimak. Secara deskriptif data pretest dan postest untuk keterampilan menyimak dapat dilihat pada Tabel 2.

Tabel 2

Hasil Analisis Deskriptif Pretest dan Postest Keterampilan Berpikir Induktif Kelas Eksperimen dan Kelas Kontrol

\begin{tabular}{|c|c|c|c|c|c|c|c|c|}
\hline & Kelas & $\mathbf{N}$ & Min & Max & Mean & Modus & Median & SD \\
\hline Pretes & \multirow{2}{*}{ Eksperimen } & \multirow{2}{*}{28} & 25 & 90 & 52,3 & 39,5 & 35,5 & 18,08 \\
\hline Postes & & & 51 & 98 & 80,2 & 87,3 & 83,5 & 12,1 \\
\hline Pretes & \multirow{2}{*}{ Kontrol } & \multirow{2}{*}{28} & 20 & 90 & 53 & 48,3 & 48,3 & 16,9 \\
\hline Postes & & & 40 & 90 & 58,1 & 53 & 55,2 & 12,3 \\
\hline
\end{tabular}

Berdasarkan Tabel 2, nilai pretest pada kelompok eksperimen menunjukkan nilai minimum 25 dan maksimum 90 dan untuk nilai postest menunjukkan nilai minimum 51 dan maksimum 98. Kelompok kontrol nilai pretest menunjukkan nilai minimum 20 dan 
maksimum 90 dan untuk nilai postest menunjukkan nilai minimum 40 dan maksimum 90. Sehingga disimpulkan nilai pretest maupun postest kelompok eksperimen lebih tinggi dari kelompok kontrol. Hal ini juga dapat dilihat pada Tabel 3 :

Tabel 3

Ringkasan nilai pretest dan postest

\begin{tabular}{|l|c|c|}
\hline \multicolumn{1}{|c|}{ Kelas } & Rata-rata nilai pretes & Rata-rata nilai postes \\
\hline Eksperimen & 52,3 & 80 \\
\hline Kontrol & 53 & 65 \\
\hline
\end{tabular}

Pada Tabel 3, menunjukkan bahwa kelas eksperimen lebih tinggi dari kelas kontrol, kedua kelas tergolong dalam kategori sedang. Berdasarkan hasil analisis uji t pada variabel keterampilan menyimak. Antara kelompok eksperimen dan kelompok kontrol ditunjukkan pada Tabel 3.

\section{Tabel 4}

Uji-t Tes Akhir Keterampilan Menyimak

Kelas Eksperimen dan Kelas Kontrol

\begin{tabular}{|c|c|c|}
\hline \multirow{2}{*}{ Uji-T } & $\mathbf{T}_{\text {hitung }}$ & $\mathbf{T}_{\text {tabel }}\left(\mathbf{1}-\frac{\boldsymbol{\alpha}}{\mathbf{2}}\right)^{\mathbf{t}}\left(\mathbf{n}_{\mathbf{1}}+\mathbf{n}_{\mathbf{2}}-\right.$ \\
& & $\mathbf{2})$ \\
\cline { 2 - 3 } & 7,55 & 2,00 \\
\hline
\end{tabular}

Berdasarkan Tabel 4, menunjukkan $\mathrm{t}_{\text {hitung }}=7,55$ lebih besar dari $\mathrm{t}_{\text {tabel }}=2,00$ untuk $\mathrm{db}=58$ pada $\alpha=5 \%$. karena $\mathrm{T}_{\text {hitung }}>\mathrm{T}_{\text {tabel }}$ maka $\mathrm{H}_{0}$ ditolak dan hipotesis alternatif $\left(\mathrm{H}_{1}\right)$ diterima. Dapat diartikan bahwa terdapat pengaruh terhadap keterampilan berpikir induktif yang diberikan model pembelajaran Suggestopedia dengan yang dib eri model pembelajaran konvensional.Hasil pengujian ini sekaligus membuktikan bahwa terjadi pengaruh pada hasil keterampilan berpikir induktif ipa siswa bukan suatu kebetulan, melainkan karena perbedaan perlakuan yang diberikan pada kelas eksperimen dan ke las kontrol. Sehingga dapat disimpulkan bahwa dengan memberikan perlakuaan menggunakan model pembelajaran Suggestopedia dapat berpengaruh positif terhadap 
keterampilan berpikir induktif siswa, serta efisiensi proses belajar mengajar IPA dapat ditingkatkan menggunakan model pembelajaran Suggestopedia.

Setelah dilakukan pembelajaran materi teks fiksi dan nonfiksi dengan model pembelajaran Suggestopedia pada kelas eksperimen dapat mempengaruhi keterampilan berpikir induktif siswa, dikarenakan model pembelajaran tersebut memiliki kelebihan seperti siswa tidak diam sama sekali di kelas, mendorong siswa untuk meningkatkan inisiatif atau partisipasinya pada saat pembelajaran, siswa menjadi aktif dalam proses pembelajaran, dan menumbuhkan kebiasaan pada siswa untuk saling mendengarkan/ menyimak, berbagi, memberikan masukan, dan keterbukaan terhadap tanggapan/kritik dan meningkatkan motivasi belajar siswa.

Proses pembelajaran yang demikian, mengakibatkan kegiatan pembelajaran pada kelas eksperimen dan kelas kontrol berpengaruh terhadap keterampilan berpikir induktif siswa. Pada kelas eksperimen yang diberikan model pembelajaran Suggestopedia memberikan pengaruh lebih baik terhadap keterampilan berpikir induktif siswa dibandingkan dengan pembelajaran melalui model pembelajaran konvensional. Dimana siswa sudah mampu menambah percaya diri jika diperintah untuk maju dan berbicara di depan kelas. Sehingga, siswa di dalam kelas pada saat proses pembelajaran tidak ada yang diam sama sekali karena setiap siswa diberikan kesempatan untuk maju dan berbicara ke depan kelas menyampaikan materi yang sedang diajarkan. Dengan demikian model pembelajaran ini dapat meningkatkan motivasi belajar pada siswa, dan pada saat proses pembelajaran berlangsung keterampilan berpikir induktif pada siswa dapat meningkat lebih baik.

Meskipun model pembelajaran Suggestopedia ini berhasil dalam meningkatk an keterampilan berpikir induktif siswa, namun masih ada beberapa kendala yang dialami pada saat penelitian berlangsung, terutama dikelas eksperimen yang sebelumnya dalam pembelajaran dikelas siswa masih kurang percaya diri. Pada model pembelajaran Suggestopedia ini siswa yang harus lebih banyak terlibat dalam pembelajaran, serta setiap siswa diberikan kesempatan untuk berbicara di depan kelas. Dengan demikian, peneliti perlu untuk mempersiapkan waktu yang cukup lama dan juga bahan ajar yang mudah dimengerti dan menarik bagi siswa sehingga dapat membangkitkan semangat untuk belajar dan aktif dalam pembelajaran yaitu salah satunya dengan memberikan reward kepada siswa serta menghargai setiap pekerjaan yang telah siswa lakukan. 


\section{SIMPULAN DAN SARAN}

Hasil penelitian dapat disimpulkan bahwa hasil perhitungan uji hipotesis dengan uji-T didapat perhitungan bahwa $t_{\text {hitung }}=7,55$ sedangkan $t_{\text {tabel }}=2,00$ den gan demikian $t_{\text {hitung }}>t_{\text {tabel }}(\alpha=0,05)$, maka $\mathrm{H}_{0}$ ditolak dan $\mathrm{H}_{1}$ diterima. Berdasarkan hasil belajar y ang didapat, dapat disimpulkan bahwa terdapat pengaruh keterampilan berpikir induktif pada siswa yang belajar menggunakan model pembelajaran Suggestopedia dibandingkan dengan model pembelajaran konvensional.

Berdasarkan hasil penelitian yang telah dilakukan, menunjukkan bahwa dengan menggunakan model pembelajaran Suggestopedia terdapat pengaruh terhadap keterampilan berpikir induktif pada siswa kelas IV. Pada saat penerapan pembelajaran di kelas dengan menggunakan model tersebut dapat membuat siswa lebih aktif dan termotivasi dalam belajar, karena pembelajaran yang dilakukan lebih bany ak melibatkan siswa di dalamnya sehingga siswa lebih mudah paham terhadap materi pelajaran yang diberikan, dan tidak ada siswa yang diam sama sekali pada saat proses pembelajaran berlangsung.

Dapat dikatakan pembelajaran di kelas berjalan dengan lancar dan mendapatkan hasil yang baik. Sehingga model pembelajaran Suggestopedia dapat diterapkan di kelas oleh guru untuk memberikan variasi pada proses pembelajaran agar pembelajaran tidak cepat terasa bosan..

\section{DAFTAR PUSTAKA}

Arsyad, Azhar. (2010). Bahasa Arab dan Metode Pengajarannya. Yogyakarta: Pustaka Belajar.

Arikunto, Suharsimi. (2013). Dasar-Dasar Evaluasi Pendidikan. Jakarta: PT. Bumi Aksara.

Huda, Miftahul. (2013). Model-Model Pengajaran dan Pembelajaran. Yogyakarta: Pustaka Belajar.

Joyce, Bruce dkk. (2009). Models Of Teaching Model-Model Pengajaran. Yogyakarta:Pustaka Belajar.

Jihad, Asep dkk. (2013). Evaluasi Pembelajaran. Yogyakarta: Multi Pressindo. 
Riadi, Edi. (2014). Metode Statistika Parametrik \& Nonparametrik. Tangerang: PT.Pustaka Mandiri.

Rusyana, Adun. (2014). Keterampilan Berfikir. Yogyakarta: Ombak.

Sudjana, Nana. (2015). Penilaian Hasil Proses Belajar Mengajar. Bandung: PT. Remaja Rosdakarya Offset.

Sugiyono. (2016). Metode Penelitian Kuantitatif, Kualitatif, dan R\&D.Bandung: Alfabeta

Sudjana.(2005). Metode Stastika. Yogyakarta: Graha Ilmu.

Sumantri, Mohamad Syarif.(2015). Strategi Pembelajaran. Jakarta: PT. Raja Grafindo Persada.

Susanto, Ahmad. (2013). Teori Belajar dan Pembelajran di Sekolah Dasar. Jakarta: Kencana Prenada Media Group.

Samatowa, Usman. (2016). Pembelajaran IPA di Sekolah Dasar. Jakarta: Indeks.

Sulistyanto, Heri. (2008). Ilmu Pengetahuan Alam untuk SD dan MI Kelas IV. Jakarta: Pusat Pembukuan Departemen Pendidikan Nasional.

Taringan, Henry Guntur. (2009). Metodologi Pengajaran Bahasa2. Bandung: Angkasa. Trianto.(2015). Model Pembelajaran Terpadu. Jakarta: Bumi Aksara.

Winarni, Endang Setyo. (2015). Matematika Untuk PGSD. Bandung: PT. Remaja Rosdakarya Offset. 